\title{
МУЗИЧНА СЕМІОЛОГІЯ ЯК АКТУАЛЬНИЙ НАПРЯМ ТЕОРІЇ МОВНОЇ СВІДОМОСТІ
}

\author{
Самойленко О. І., Осадча С. В.
}

\section{ВСТУП}

Як наукова академічна дисципліна, що набуває значного освітнього резонансу та стає необхідною складовою частиною музично-навчальної практики на iї вищих освітньо-кваліфікаційних рівнях, музична семіологія визначає свій поняттєвий апарат на перетині основних розділів музикознавства, таких як історія музики та теорія й аналіз музичних форм, музична естетика та теорія музичної інтерпретації, деяких інших, тобто виявляє перехідні методичні здатності, зумовлені ії предметними орієнтирами та широтою залученого до пізнавального поля матеріалу.

Перефразовуючи висловлення У. Еко ${ }^{1}$, відзначимо, що музична семіологія нині постає дисципліною, що не лише активно розвивається, а й самовизначається, шукаючи власні предмет та методи, починаючи виразно претендувати на інтегративне міждисциплінарне положення, на роль загальної теорії музики, якщо під останньою розуміти складносистемне знакове утворення, що має іманентні ресурси символізації та діяння, врешті-решт виявляється цілісною мовною сферою, що передбачає специфічні принципи комунікації - спілкування.

На відміну від музичної семіотики та теорії музичної семантики, семіологія шукає вихід у широкий простір не лише культури, а й метакультурних онтологічно-транцендентальних передумов людського мислення й спілкування, звертається до того досвіду, що $є$ «началом усіх начал», адже пояснює причини будь-якої знакової діяльності людини, потреби людської спільноти у виробленні мови та у мовному бутті. Але найбільше вона зумовлюються потребою визначення генезису музичної мови як мови свідомості, що відкриває людині ії справжню смислотворчу реальність, тому музично-семіологічне вивчення спрямоване до специфічних способів організації знакової форми та смислозначеннєвого змісту.

\section{1. Музична семіологія в структурі сучасного музикознавства та в системі наявних гуманітарних дисциплін}

Виходячи з деяких міркувань У. Еко, зазначимо, що соціокультурна природа людини, невід’ємна від природно-біологічних умов іiї існування, злита з їі (людини) мовними проявами.

\footnotetext{
1 Эко У. Отсутствующая структура. Введение в семиологию. / Пер. с итал. В. Резник и А. Погоняйло. Санкт-Петербург : «Симпозиум», 2004. С. 491-492. 
Надалі кожен, хто хоче пояснити феномен комунікації, якщо він є послідовним, повинен враховувати, що:

a) мова передує людині і навіть засновує їі як таку;

б) не людина говорить тією чи іншою мовою, але мова «промовляє» людину.

Ствердження (б) зовсім не означає, що людина завжди повинна думати і спілкуватися на основі соціально детермінованих кодів, цей висновок нас дуже влаштовує із семіотико-методологічної точки зору, він важливий як вихідний пункт для розробки семіотики, яка завжди намагається показати, на основі яких наявних соціальних і історичних кодів люди спілкуються. Але ця передумова має на увазі, що мова «промовляє» людину згідно з тими законами і правилами, які людині не дано пізнати.

Стало бути, структури різних мов і історично сформовані коди можуть існувати, але це не структура мови як такої, не якась Прасистема, не Код кодів. Останній ніколи не стане нашою здобиччю. Ніяке металінгвістичне вивчення елементарних механізмів мовної діяльності неможливе саме тому, що в основі нашого говоріння про механізми такої діяльності лежить сама мова. Вивчати мову - значить лише запитувати мову, даючи ій жити власним життям.

Мова ніколи не буде тим, що ми мислимо, але буде тим, у чому здійснюється думка. Отже, говорити про мову не означає виробляти пояснювальні структури або докладати правила мови до якихось конкретних культурних ситуацій. Це означає давати вихід усій iї конотативній могутності, перетворюючи мову на акт творчості, 3 тим, щоб у цьому говорінні можна було розчути поклик буття. Слово не $\epsilon$ знаком. У ньому розкривається саме буття. Така онтологія мови умертвляє всяку семіотику. Місце семіотики займає єдино можлива наука про мову - поезія, ecriture.

Отже, будь-яке дослідження структур комунікації виявляє не якусь структуру, що залягає в глибині, а відсутність структури, локус безперестанної «гри».

На зміну двозначної «структуралістської філософії» приходить щось нове ${ }^{2}$.

Цим новим, продовжимо думку У. Еко, і стає семіологія, а у разі іiі залучення до вивчення своєрідності музичної мови, тобто мови музики музична семіологія. Таким чином, націленість на мовну діяльність, прагнення «розгадати» таємниці мовної дійсності людини тією мірою, що дає змогу судити про «поклики буття», «розпитати» мову про творчі механізми буттєвої гри, до якої виявляється включеною людина 3 іiі

\footnotetext{
2 Эко У. Отсутствующая структура. Введение в семиологию. / Пер. с итал. В. Резник и А. Погоняйло. Санкт-Петербург : «Симпозиум», 2004. С. 30-31 (тут і далі пер. укр. наш).
} 
мовною свідомістю, може розглядатися як головна передумова, відправний пункт формування семіології. I невипадково дослідник пропонує звертатися до такої мовної сфери, у якій вона найбільш повно реалізує свої онтологічно-смислові покликання, - до поезії, тобто художнього середовища, найвільнішого у самовиявленні та самозростанні. Йдеться не лише про словесну поезію, а й про будь-які художньо-знакові системи, що здатні набувати функцій мовних, тобто здійснювати комунікативний процес у його необхідній ігровій свободі та змістовій буттєвій повноті. Недарма на самому початку свого дослідження італійський учений зауважує, що семіологія передбачає розгляд усіх явищ культури (а також і певних природних процесів у тваринному світі) як знакових систем, припускаючи, що всі вони $\epsilon$ феноменами комунікації, тобто існують у детермінованому буттєвими закономірностями зв'язку ${ }^{3}$.

Окрім цього, загальний хід міркувань У. Еко, який звертається до понять про означаюче та означене, в останньому знаходячи «витоки» смислу, а в сприйнятті знакової форми - його справжнє народження, активізує логіку герменевтичного аналізу, що апелює до розуміння, тобто до процесу «безперервного запитування»; це запитування про ті значення, котрі стають «епохальними», водночас входять до різних ідіолектів, також провокуються останніми, тобто перебувають у постійно-змінному стані, є стабілізованими та рухливими водночас так само, як невіддільними та незлитними ${ }^{4}$. Тому вони потребують саме семіологічного підходу, а такий підхід, відповідно, виявляється сфокусованим на процесі породження та трансляції значень як еманацій буттєвих смислів за допомогою художньо-знакової (мовної) форми.

Отже, на нашу думку, доцільно визначати об ' $є$ мm музичної семіології як актуальний текстовий простір та текстологічні умови музики, у тому числі в історичних зв'язках та «енактиваціях», «вдіюваннях». Предметом музично-семіологічного пізнання при цьому постає єдність та взаємодія смислового змісту (породжуваних смислів), знакової природи/форми та мовних якостей/показників/критеріїв музики як процесу та результату міжособистісної (міжіндивідуальної) людської комунікації.

Методи та категоріальний апарат музичної семіологї зумовлені багатошаровістю того музично-текстового матеріалу, який вона вимушена залучати, й вихідними стають історико-компаративний та структурно-аналітичний методи, що спираються на жанровокомпозиційний, стильовий та стилістично-хронотопічний підходи, з їх власною парадигматикою та дискурсивними властивостями, специфічною термінологією.

\footnotetext{
${ }^{3}$ Там само. С. 43.

${ }^{4}$ Там само. С. 32.
} 
Але не менш важливими й категоріально аргументованими постають методичні позиції суміжних наук, таких як філософська герменевтика, естетика, епістемологія, теоретична психологія, соціологія, філологія та структурна лінгвістика, мовознавство, історія культури тощо. Власне, все наявне коло людинознавчих дисциплін $\epsilon$ спорідненим 3 тими реаліями буття людини в мові та 3 мовою, у сигніфікованому та символізованому просторі освоєного життя, котрі намагається вивчати семіологія - музична семіологія. Адже вона пропонує сприймати й розкривати призначення музичного мистецтва як однієї з провідних мов сукупного людського цивілізованого існування, сукупної та водночас індивідуалізованої людської свідомості. Таким шляхом музична семіологія здатна входити до галузі питань про походження мовної свідомості людини та іiі різновиди, зокрема як про природно-зумовлене і трансльоване психофізіологічним способом, та водночас штучно сформоване й запроваджене ззовні, екстернальними засобами, до знаково-мовної практики міжособистісного спілкування.

Специфічні дискурсивні риси та властивості музичної семіології значною мірою визначаються іiі основоположними категоріями, серед яких на перший план виходять смисл - знак - значення - текст реальність; головна теоретична магістраль прокладається взаємодією понять мови та свідомості. Незважаючи на загальновизнану складність, відкритість та полемічність наведених понять, справжнє призначення музичної семіології полягає в тому, щоб установлювати межі та критерії розуміння й усвідомлення-перетворення музичних смислів 3 усією необхідною широтою й глибиною, разом із тим з достатньою чіткістю та достовірністю, виходячи зсередини, зі змісту самого музичнотворчого процесу.

Можна вважати музичну семіологію необхідною базовою дисципліною у професійній підготовці музикознавців та музикантівпрактиків будь-якого профілю: не викликає жодного сумніву важливість володіння тією мовною системою, яка $\epsilon$ засадничою у вибраній сфері комунікації. Як і низка інших наук про музику, музична семіологія розпочинається зі спроби формування окремої пізнавально-освітньої сфери та своєрідного дидактичного упорядкування, вирівнювання суперечливих «різновисотних» теоретичних положень задля того, щоб зробити їх доступними для обговорення.

Як академічна освітня дисципліна музична семіологія може бути представлена у тому порядку, у якому вибудовується іiї термінологічний апарат, включає три основні тематичні розділи, серед яких кожен наступний продовжує, поглиблюючи та збільшуючи, деталізуючи аналітичним шляхом, зміст попереднього. 
Так, розділ 1 присвячується розгляду музичної семіології в системі сучасного гуманітарного знання з визначенням іiї витоків, теоретичних передумов, предмета та поняттєво-дискурсивного тезаурусу. До його провідних питань входять питання про смисл і розуміння, іманентний логос музики та способи виявлення музичного смислу; про діалог як смисловий феномен та діалогічні аспекти художньої (музичної) комунікації; про природу i побудову смислової реальності; про естетичне, етичне і ноетичне відношення, образ - знак - символ у художньо-мовній (музичній) реальності.

Розділ 2 переводить до теми взаємодії ноетичних категорій та семіологічних констант музики, передбачає вивчення підходів до музичної мови, виявлення її знакових та значеннєвих підстав, серед яких виокремлюються «пам'ять культури» і культура як пам'ять, жанрова та стильова форми пам'яті в музичній творчості; феномени любові та гри, встановлюються специфічні звукові еталони музичного смислотворення.

Розділ 3 розгортається у спиранні на текстові утворення в музиці та на текстологічні константи музичного мовлення й мислення, веде від смислового значення до текстової формули, i навпаки, дає змогу розвивати поняття про музичний текст та ієрархію текстологічних рівнів у музиці, інтертекстуальність і гіпертекст, прямує до виявлення типологічних властивостей музичної мови - музичної свідомості, як наслідок, до семіологічної типології музики.

Загальною метою всіх трьох розділів музично-семіологічної освітньонаукової розвідки є встановлення теоретичного цензу поняття про «музичне» у різних аспектах його докладання та застосування, але завжди у широкому естетико-семіологічному розумінні як сталої гіпостази поняття про «людяне». Не лише це поняття, а й загалом музичне звучання постає синонімом людської вродженої здатності (потреби) породжувати та усвідомлювати смисли, створювати власний інтенціональний світ.

Широта та універсальність музичного діяння як входження музичної мови до «смислового світу» культури роблять актуальними такі способи/рівні характеристики музичної творчості як комунікативного феномена: - вимірювальні (парадигматичні) опозиції: особистість соціум або суб'єкт (людина) - час; музика - історія (автор - музика). Може виникати деяка опозиція: соціальна культура - музичне мистецтво, через яку проступає протиставлення історичного життєвого досвіду (включаючи особистісно-авторський); музичної мови, взагалі мови як форми збереження і передачі досвіду; - базові (вихідні) передумови становлення музичної мови, що зумовлюють критерії ї оцінки: комунікативні процеси; дискурсивні поля; символізація провідні символічні форми; співвідношення соціального i 
персоналізованого в людині, творчі ресурси особистості; психологічні інструменти; полікультурність сучасної музичної практики; перехідність і маргінальність; полілінгвальність буденної і художньої свідомості; диференціація сфер музичної комунікації: повсякденна естетична (з частковою спеціалізацією); прикладна, професійно-масова (з прикладними естетичними функціями); передхудожня аматорська, професійномасова художня; позаакадемічна/неакадемічна; академічна професійна, автономно-художня.

Усе перераховане вказує не лише на соціокультурні чинники музичної семіологіï, а й на важливість питання про «антропологічне середовище» як джерело конотативних властивостей музичного тексту що підтверджується музикознавчими та психологічними дослідженнями останніх років ${ }^{5}$.

Спільною з іншими антропологічними дисциплінами стає для музичної семіології і категорія часу, котра супроводжує музикознавство на всіх його пізнавальних рівнях: аксіологічному культурно-семантичному, праксеологічному жанровому, музично-стильовому текстологічному, нарешті на мовному як на рівні глибинної генеративної поетики музики. Так, змінюють одна одну форми часових уявлень, що утворюють послідовність епістем - пізнавальних установок: «час культури», жанровий час як певний історичний час музики, стильовий час як образно-символічний ідеаційний, що запускає механізм концептуалізації, a також композиційний час як суміжний між попереднім стильовим $\mathrm{i}$ наступним, мовним, рівнями; останній виступає як час i місце безпосереднього створення і виконання музичного твору.

Через композиційний час - способи його організації, тобто на межі стильового i знаково-стилістичного кіл, набуває актуальності i конкретизацію поняття сучасної музичної мови або мови сучасної музики, саме в зв'язку з іманентним логосом музики, тобто в понятійно «чистому» й абсолютному значенні, як те, що створено в хронологічно найближчому контексті i часто ще не має визначених жанровостильових показників, тому вимагає безпосередніх осягань якостей музичного тексту - освоєння, оцінок, буквальної співпричетності йому, у тому числі аналітичного проникнення в музично-звуковий матеріал.

Але слід пам'ятати, що у кожної історичної епохи була така - своя найближча сучасність, тобто слід пам'ятати, що сучасність - це різновид історичної ситуації. Тому у разі звернення до віддалених хронологічно

\footnotetext{
5 Стогний И. Коннотативные свойства музыкального текста : монография. Москва : РАМ им. Гнесиных. 2013. 224 с.

Стогний И. Процессы смыслообразования в музыке (семиологический аспект) : дисс. доктора искусствоведения; спец. : 17.00.02 «Музыкальное искусство». Москва : РАМ им. Гнесиных, 2013. $416 \mathrm{c}$.

Торопова А. Интонирующая природа психики: музыкально-психологическая антропология : монография. 2-е изд. Москва : МПГУ, 2018. 338 с.
} 
музично-історичних мовних явищ потрібні свідчення (важливі прямі свідки) в формі слухацьких відгуків, критичних нотаток, дослідницьких праць, мемуарних записів і т. д.

Взаємодія ціннісного досвіду музики і можливості його смислового збереження - реконструкції, інтерпретативної реорганізації - зумовлена знаково-значимою природою часу в музиці, тобто звучними особливостями музичного часу, його специфічною мовною природою.

\section{2. Категорія смислу в контексті музичної семіології}

Можна вважати визнаним, що висловлені музикою смисли специфічні тільки і саме для неї; вони унікальні і в художньому, і в загальному життєвому онтологічному призначенні, оскільки відтворюють (створюють) найбільш вершинні і найбільш глибинні рівні людського буття. Але те, що можливість їх продукування пояснюється принципами музичної форми як семіологічного феномена, тобто як спеціалізованої мовної сфери, породжуваної універсальною людською потребою в особистісній естетичній довершеності переживання смислу життя (буття), все ще потребує доведення та підтвердження.

Уявлення про форму в його можливій музикознавчій презентації, звичайно, якщо звільнити його від звужуючих технологічних підходів, просувається 3 більш загального культурно-історичного і життєвого контексту до сфери побудови музичного тексту і розуміння музики як тексту, потім до параметрів організації умовного семантичного простору музики, до його інтексту - сукупності специфічних музичних художніх інтенцій. Таким чином, виникає рух музикознавчої думки від зовнішньої формальної організації музичного мистецтва, музично-творчого процесу до його іманентних закономірностей, до внутрішньої «мови» музики як до тієї іiі внутрішньої форми, що $\epsilon$ ключовим психосемантичним фактором музичного діяння (еманації смислових значень засобами музичного звучання).

Припускаємо і більш сильне твердження, що питання про внутрішню форму, як і саме це явище, пов'язані з головним значеннєво-мовним законом музики; пізнання цього закону, обговорення його сторін і складників дає змогу прояснювати «важкі проблеми» свідомості, перед якими зупиняються нині представники не тільки гуманітарних, але i природничих наук. Мистецтвознавча методологія, яка залучає семіологічні підходи, може сприяти вирішенню деяких складних питань в об'ємній сфері людинознавства, в тому числі і в зв'язку з вивченням когнітивних процесів і способів їх моделювання. Передумовою цього стає та особлива єдність форми і смислу, яку виявляє знаково-мовна організація музичного мистецтва. 
Діалогічний підхід у єдності 3 історико-порівняльним виступає головною методичною умовою музичної семіології; але чим він найбільш корисний для музично-семіологічного пізнання?

По-перше, як шлях до смислу, оскільки діалог і смисл $є$ взаємно породжуваними континуальними явищами, що діють на різних рівнях буття та свідомості людини та у різних вимірах комунікативного процесу. Про це яскраво свідчать праці М. Бахтіна, що розробив цілісну теорію діалогу на рівнях «філософії життя», естетичної діяльності, жанрової літературної форми, стилю та стилістики літературного тексту ${ }^{6}$.

По-друге, як шлях до пріоритетних форм розуміння, зокрема до феноменологічного та ноологічного способів виявлення творчих здатностей людської свідомості. Про це свідчить суттєва близькість так званих ноосферних явищ та музичних символів, так само, як і ноетична інтенціональна зумовленість музичної творчості. Наближення семіологічних та ноологічних категорій відбувається на рівні загальних настанов поетики та семантики музики, але вони визначають i внутрішню знаково-мовну іманентну музичну гру ${ }^{7}$.

Три опорні, граничні, «заповітні» смислові інстанції - Пам’ять, Гра, Любов - відповідають сакральному, когнітивному й особистісному «людяному» - смисловим началам культури. 3 боку музичної поетики такими інстанціями стають жанр - композиція (форма твору) - стиль (авторська присутність у музиці, авторське особистісне «не-алібі-вбутті» музики). Смисл стає зрозумілим, набуває логічної доступності, «популярності» тільки тоді, коли проговорюється в слові. Музичний смисл не є винятком, але у нього є свої, інші, особливі ресурси, свої символічні таємниці, «зона невідомості». Нам видається важливим підкреслювати не-рівність музичного смислу як знаками, так i значенням (у разі вільно-діалогічних відносин між останніми), як і те, що найвищу активність виявляє саме значення: воно менше смислу і більше знаку (однієї «речової» форми смислу), завжди перебуває в русі між ними, створюючи («виплітаючи») «семантичну тканину» музики.

\footnotetext{
${ }^{6}$ Бахтин М. Автор и герой в эстетической деятельности. Эстетика словесного творчества. 2-ое изд. / Сост. С. Бочаров. Прим. С. Бочарова и С. Аверинцева. Москва : Искусство, 1986. С. 9-191.

Бахтин М. К философии поступка. Работы 1920-х годов. Киев : Наукова думка, 1994. С. 9-68.

Бахтин М. Слово в романе. Вопросы литературы и эстетики. Исследования разных лет. Москва : Художественная литература, 1975. С. 72-233.

Бахтин М. Эпос и роман. Вопросы литературы и эстетики. Исследования разных лет. Москва : Художественная литература, 1975. С. 447-483.

Бахтин М. Проблема текста в лингвистике, филологии и других гуманитарных науках. Литературно-критические статьи. Москва : Художественная литература, 1986. С. 473-500.

Буш Г. Диалогика и творчество. Рига : Авотс, 1985. 318 с.

Wertsch J.V. The significance of dialogue in Vygotsky's account of social, egocentric, and inner speech. Contemporary Educational Psychology, No. 5, 1980. Pp. 150-162.

7 Самойленко А. Культурологическая концепция диалога М. Бахтина и методологические проблемы музыкознания. Культурологічна трансформація мистецької освіти та актуальні питання творчої діяльності музиканта в сучасній Украйні. Збірник наукових праць. Київ, 1998. С. 21-37.

Самойленко А. Музыковедение и методология гуманитарного знания. Проблема диалога. Одесса : Астропринт, 2002. 244 с.
} 
Сенс і символ (знаково-значуща форма смислу) зустрічаються в точці ідеального Над-адресата, що представляє повноту розуміння. Цю зустріч можна називати зустріччю свідомостей - рух суб'єктів діалогу 3 протилежних позицій, їх протистояння та єдність. Ї̈і метою стає «боротьба матеріалу і форми», за Л. Виготським, «подолання себе», за М. Бахтіним, як боротьба за смисл, за відкриття нового смислозначимого простору буття. За словами М. Бахтіна, не можна змінити буття матеріально, можна змінити тільки смисл буття. Уточнимо: можна і варто змінювати значення смислу, його проєкції до людської реальності за допомогою людської свідомості, оскільки самі смисли також не піддаються прямим змінам, адже вони $є$ спільною, хоча й невидимою, матерією свідомості. За словами Виготського, «те, що я мислю речі, які поза мною знаходяться, в них нічого не змінює, але те, що я мислю афекти, що я ставлю їх в інше ставлення до мого інтелекту і інших інстанцій, багато що змінює в моєму психічному житті» ${ }^{8}$

Тому головний пізнавальний інструмент семіологічного аналізу - це саме діалог як «зустріч» різних вимірів реальності та різних способів усвідомлення. Важливість такого діалогу багаторазово підтверджується різнобічністю, антіномічністю життя і культури, біполярністю буття культури i дуальністю особистісного психологічного буття. Кожне значуще явище породжує свою протилежність, що, за П. Флоренським, зумовлене вихідною антиномією родового та особистого, усійного та іпостасного в людині, роздвоєнням іiі свідомості на «правду землі» і «правду неба», пережитим як загальна «трагічна вина». Ціннісносмислова роздвоєність буття знімається в сакральній символіці, і це пояснює роль «сакрального» як однієї з універсалій культури, що продукує «велику символіку» людського спілкування.

До такої символіки мова музики є причетною за основними умовами формування, і саме вона визначає особливості асоціативного сприйняття музики - мнемонічні глибини музичного переживання та конотативну широту музичного смисло-значення, мобільність та постійну рухливість музичної пам'яті як естетичної, тобто пам'яті про естетично значущі часові відносини в музиці, котрі так чи інакше позначилися в іiі композиційній формі.

Приховане та явне (імпліцитне та експліцитне) у музичному смислотворенні також утворюють своєрідну діалогічну структуру та

\footnotetext{
${ }^{8}$ Выготский Л. О психологических системах. Собр. соч. в 6-ти томах. Т. 1. / Под ред. А. Лурия, М. Ярошевского. Москва : Педагогика, 1982. С. 126.

Див. також: Выготский Л. Проблема сознания. Собр. соч. в 6-ти томах. Т. 1. / Под ред. А. Лурия, М. Ярошевского. Москва : Педагогика, 1982. С. 156-167.

Выготский Л. Мышление и речь. Собр. сочинений: в 6 т. Т. 2. Москва : Педагогика, 1982. С. 361.

9 Флоренский П. Из богословского наследия. Богословские труды. Москва, 1977. T. XVII. C. $140-142$. 
впливають на способи семіологічних характеристик музичного контенту.

Головним тут постає опосередкованість/конвенціональність як смислового змісту, так і виявлення його значеннєвих проєкцій у музичному звучанні. При цьому смислова свідомість як справжнє внутрішнє життя, епіцентр людської свідомості (осередок самоусвідомлення) залишається першим джерелом енергії мовного самовияву.

Яким чином сприймається смисл, породжуваний зсередини свідомості? Як розподіляються внутрішні та зовнішні, з боку наявної системи музичної виразовості, визнаної музичної мови, чинники смислотворення в музиці? Якою мірою узгоджені між собою ідеї внутрішньої та зовнішньої гармонії, що відтворюються в музиці та почасти творяться нею?

Ці та деякі інші питання примушують вивчати можливі взаємозв'язки між ноологією та музичною семіологією, також ноосферою та «фоносферою»; спираючись на теоретичні позиції М. Тараканова ${ }^{10}$, можна стверджувати особливу роль слухового сприйняття, слухової свідомості у смислотворчій активності людини, а сам смисл характеризувати як «відчутий», тобто «прослуханий» зсередини свідомості, відновлюваний нею.

Визнання слухання головним способом сприйняття й відтворення смислового змісту буття виводить явище музичного звуку на центральні теоретичні позиції у пізнавальній системі музичної семіології.

Генералізуючі знакові функції музичного звуку, що потребують i підсилення ролі поняття про музичне звучання, підтверджуються ставленням М. Арановського до звуку як до провідника у царину езотеричного, космічного та божественного; на думку Арановського, саме звук є тим об'єктом, над яким проводяться мисленнєві операції, тобто $\epsilon$ матеріалом усвідомлення та когнітивного упредметнення, водночас особливим засобом, інструментом нового упорядкування відомостей про світ. Оскільки музичне мислення $\epsilon$ аудіальним мисленням, що базується на певних слухових уявленнях, «звук постає перед нами мовби оточений духовною аурою...»" ${ }^{11}$ Тому буття звуку в музиці та музичного звуку в культурі - від пристосувально-орієнтовної функції до символізуючої, а також різні музичні способи семантизації звуку входять до головного предметного кола музично-семіологічного дослідження; звернена до них семіологічна теорія здатна утворювати «вищий ступінь розуміння» смисло-значеннєвої природи музики ${ }^{12}$.

\footnotetext{
10 Тараканова Е. Концепция фоносферы на рубеже тысячелетий. Звуковая среда современности : сб. ст. памяти М. Тараканова (1928-1996). / Отв. ред.-сост. Е. Тараканова. Москва : ГИИ, 2012. С. $27-41$.

11 Арановский М. Музыка. Мышление. Жизнь: статьи, интервью, воспоминания. Москва : ГИИ, 2012. C. $60-61$.

${ }_{12}$ Там само. С. 62.
} 


\section{3. Від поняття знаку до теорії музичного значення}

Перш за все зізнаємося, що традиційна структуралістськапостструктуралістська семіотична термінологія більше утруднює розуміння знаку та значення в музиці, аніж сприяє йому, хоча поняття про зазначене та те, що означає, завжди залишається важливою «парноопозиціональною» вказівкою на відстань між значеннєвим змістом та знаковою формою. Але в різних мовних системах ця відстань приймає різні топологічні показники, особливо коли йдеться про звук та артикуляційні форми, що $є$ принципово різними явищами у музичному звучанні та у словесному мовленні. Певні виключення можна знайти у поетичному слові, що вбирає ознаки й прийоми музичного інтонування. Але головні відмінності залишаються незмінними. Вони залежать, поперше, від місцезнаходження звуку (ззовні, у площині життєвої реальності, чи всередині, у сфері відчуття - усвідомлення); по-друге, від відношення знаку - значення, оскільки у словесному матеріалі значення формується на основі знаку, після знаку, на його визначеній предметній основі, а в музичному звучанні значення передує знаку, є більш сталим. Водночас зона його варіювання зумовлюється логічними завданнями, тобто формальними принципами організації звучання, причому власне фігури музичної логіки і є музичними знаками, що містять у собі сталі та змінні чинники звуко-смислотворення, відновлюють предметне «що» музичного звучання, забезпечують його речову презумпцію.

Звичайно, сигніфікаційні відмінності мовних систем у цілісній смислотворчій людській практиці відносні і, як справедливо зазначав Р. Барт, мова завжди є посередником між думкою, ідеєю та звуком способом висловлення. Але зараз ідеться про той іiі (практики) етап, на якому словесна i музична форми $\epsilon$ вже досить автономними та «вільними» одна від одної. Ще раз згадаємо про підхід Р. Барта, котрий вважав, що виникнення смислу є наслідком сумісного розчленування звукового та мисленнєвого матеріалу, тому мова завжди є галуззю артикуляції, а «звідси випливає, що майбутнє завдання семіології полягає не стільки в тому, щоб створити предметну лексику, скільки в тому, щоб встановити способи членування людиною реального світу...» ${ }^{13}$. Додамо, що це завдання передбачає встановлення місцеположення та якості реальності, котра супроводжує людське існування, передусім іії зовнішнє або внутрішне розташування, природний, штучний або змішаний характер.

Музичне значення, що репрезентує смисл, народжується у свідомості, завжди $\epsilon$ внутрішнім та шукає іманентного логічного рішення й представлення; словесне (інше) значення надходить із зовнішньої

\footnotetext{
${ }^{13}$ Барт Р. Основы семиологии. / Перевод с французского Г.К. Косикова. Структурализм: «за» $u$ «против» : сборник статей. Москва : «Прогресс», 1975. С. 135-139. 
соціальної сторони комунікативної практики, виражаючи діючі життєві зв'язки, котрі, звісно, доповнюються внутрішнім інтонуванням та індивідуальним осмисленням, але як вторинним фактором. Для слова смисл народжується ззовні, надходить 3 ноосфери, є узагальнюючим чинником та історичною (надісторичною) універсалією; для музики смислове значення визначається фоносферою, що поступає (відчувається) шляхом власної слухової свідомості особистості, відкриваючи свої властивості фоно-семіо-сфери, звідси внутрішньої форми, внутрішньої мови музики.

Виникнення музичного значення як звучного феномена примушує знаходити в ньому вид відчуття й перетворення звуку, тобто штучний утвір, певну «річ», але вона, ця «річ», виникає природним психофізіологічним шляхом; як творчий акт людської свідомості вона завжди $є$ позитивним ціннісним явищем, катартичним мисленнєвим продуктом. Відносно цього факт музичного звуку (елементу музичного звучання) здатен набувати «репутації» музичного знаку, точніше знаку музики як сфери самовиявлення творчої сили людської свідомості. Адже такому знаку немає аналогів у зовнішній життєвій (природній) реальності, водночас він має прототипи у власній реальності музичного мистецтва, яка владно заявляє про себе зсередини людської свідомості через слухову пам'ять, що $є$ передусім смисловою цінністю.

Внутрішні значеннєві механізми музичної мови, а також ії знакова логічна система дають змогу видобувати та експлікувати художньосмислові утворення, що (за основними показниками) $є$ специфічно музичними, унікальними, але тією ж мірою ціннісно-всезагальними. «Людина слова» $є$ абстрагованою від них; вона зумовлена наочною дійсністю, зовнішнім ходом життя, завданнями наративу та морального імперативу, що дають змогу вносити негативні означення. Музичні означення завжди залишаються суто позитивними.

Знак у музиці, відповідно до сказаного, $є$ не самим музичним звучанням, а способом його упорядкування як сталої цілісності (досить сталої), формою організації звучання на різних рівнях музичновиразової системи. Завдяки цьому музичний знак придбає мовні функції, а сама музична система може розглядатися і як специфічно-знакова, і як мовна з урахуванням внутрішньої природи музичних значень.

Знак як покажчик логічного прийому та значення як фігура музичного звучання, що репрезентує внутрішню реальність музики, такими $\epsilon$ осмислюючі, вільні та самовільні інструменти мовного визначення музики, що прагнуть бути представленими, тобто віднайти текстову презентацію.

Таким чином, музично-семіологічний трикутник смисл - значення знак, що містить у центрі явище мови, переростає на наступному 
теоретичному рівні у трикутник текст - мова - смисло-значеннєва свідомість, що передбачає у своєму змістовому осередку явище внутрішньої реальності музики як явище музично-творчої свідомості музично-мовної свідомості.

Це також дозволяє до історіологічних понять misica humana i musika mundane, запроваджених Н. Герасимовою-Персидською ${ }^{14}$, додавати семіологічне поняття музики conscientia, разом 3 яким право на існування отримують категорії авторських мовних знаків та ідіостильових значень, а уявлення про символічні можливості музичного висловлення розширюються до меж внутрішньої реальності звукового світу музики, про яку так переконливо пише Г. Орлов:

«Звучання музики - 3 найчистіших символів: частина і вісник тієї не маючої імені реальності, з якою ми вступаємо в зіткнення через музику i музичний досвід. Символічна могутність музичного звучання майже незламна, навіть коли воно інтерпретуються як об'єкт. Позбутися від неї не можуть найбільш сухі з теоретиків, переконані в тому, що оперують виключно об'єктивними даними і фактами. Для них такого роду даними служать висота звуку, його тривалість, гучність і тембр, інтервали i структури, утворені тонами, і т.п. Вони описують музичні елементи i структури в термінах синестезій і відносин, не помічаючи того, що говорять не про звук як об'єктивний феномен, а про його сприйняття, явно не тотожне звучанню і водночас невіддільне від нього.

Вимірювання слухового поля... це і є вимірювання тієї прихованої іншої реальності, яка відкривається слухачу через музичний звук і стає його внутрішньою реальністю, несвідомо, але добре знайоме чи не кожному злиття музики і душі, містичний акт, що здійснюється за допомогою символічної сили музики.

Музика возз'єднує внутрішній світ індивідуального слухача 3 його початковим грунтом, повертає його до витоків всіх природних символів - до первинних елементів досвіду людини в природному середовищі: до реальності земного тяжіння, пізнаваного через м'язові зусилля, навколишнього простору, що покривається кроками, матерії і неосяжного різноманіття іiі чуттєво сприйнятих властивостей, до реальності пориву й опору, який він зустрічає, дихання і биття серця цих первинних природних механізмів усвідомлення часу» ${ }^{15}$.

Рухливий символічний світ музики базується на іï текстовій, або текстологічній, матерії, котра, своєю чергою, виявляється як множина стилістичних конфігурацій та контамінацій. Стилістика в музиці, зі свого боку, може визначатися як «простір значень» та їх текстуальних зумовлень.

\footnotetext{
${ }^{14}$ Герасимова-Персидская Н. Звук и знак в музыкальном искусстве. Київське музикознавство: Музикознавство у діалозі. Київ-Дюссельдорф, 2011. Вип. 37. С. 12-23.

15 Орлов Г. Древо музыки. Н.А. Frager \& Со. «Советский композитор». Вашингтон-СанктПетербург. 1992. 440 с. 
Враховуючи як необхідну семантичну опозицію різницю між музичним текстом загалом та текстом музичного твору, зауважимо, що твір допускає одну-єдину стильову можливість, вираженість, позаяк стверджує одиничність композиційного здійснення жанрових та стильових настанов музично-знакової реальності, але ця одиничність існує залежно від загальної логіки тексту та способів «композиційного кодування» музичного значення.

Явище кодування та перекодування в музиці, виступаючи текстологічною парадигмою музичної історії, можна висловити формульно, якщо скористатися теоретичною моделлю семантичної пам'яті, запропонованою Й. Хоффманом ${ }^{16}$. Саме семантична пам'ять регулює відносини смислу i тексту в межах музичного тексту. Семантична репрезентація як неодмінний складник музичного тексту, будучи синтезом сприйнятого, смисло-значеннєвим відтвореннямінтеграцією отриманих слухових (образно-звукових) впливів досягає рівня знаковості в процесі стильового сприйняття-інтерпретації та інтеграції значень на «розуміючому» рівні жанрової форми. Процес семантичної репрезентації як основний для феномена семантичної пам'яті виявляє взаємозалежність звучання/значення, що фіксується у текстових формулах, наділяючи їх функціональною подвійністю предметно-речових знаків та усвідомлюючих значень. Таким чином, музична мова здійснює власну іманентну «техніку (технологію) розуміння», підтверджуючи думку про музично-текстову фігуру як «множинно-єдине», або «множинну одиничність» ${ }^{17}$. Така «техніка розуміння», що дозволяе відтворювати «...ясне диво гармонії, до кінця не зрозуміле», справді виступає єдністю дій природних та понадприродних сил, вона керує людською свідомістю, оскільки $є$ «голосом вершинного смислу всередині мене», за спостереженням М. Мамардашвілі ${ }^{18}$.

Музичні значення як «саморозуміючі» та самопороджувані явища забезпечуються внутрішнім буттям музичного тексту, що має таку генеральну властивість, як транзитивність - здатність передавати структурно-семантичні функції, знаково-значеннєві угрупування, прийоми від однієї множини стилістичних фігур через іншу далі - до нових формацій та технологічних винаходів музично-текстової реальності, що знаменується формуванням семіологічної єдності не лише тексту, а й музичного пізнання-усвідомлення.

Автономія музично-мовної свідомості базується на здатності музичного тексту, звідси іманентного часопростору музики, породжувати

\footnotetext{
16 Хоффман И. Активная память. Экспериментальные исследования и теория человеческой памяти. / Пер. с нем. К.М. Шоломия. Москва : Прогресс, 1986. 309 с.

${ }_{17}$ Мамардашвили М. Мой опыт нетипичен. Санкт-Петербург, 2000. С. 186.

${ }^{18}$ Там само. С. 197-198.
} 
власні «нескінченно великі» $\mathrm{i}$ «нескінченно малі» показники смислу; так виникає і їх співвіднесеність як діалог «великої сакральної» символіки та авторської ідіостильової, мовної стилістики в музиці. Це внутрішне існування музичної свідомості, спатіалізованої у вимірах музичного тексту, позиціонується нами як іiі самодіалог, або як «самозростаючий логос музики», дозволяючи нарешті зрозуміти справжній семіологічний сенс цього давнього аксіоматичного висловлення.

\section{4. Музично-мовна свідомість як предмет музичної семіології}

Оскільки музично-мовні значення репрезентують процес усвідомлення смислу (смислів), надходять/виникають іманентнослуховим шляхом та відображуються у структурно-семантичній логіці/технології музичного тексту, виникає можливість визначення особливостей музично-мовної свідомості як цілісного феномена, що не лише метафорично характеризує так званий «внутрішній світ» людини, а й відкриває шлях до побудови справжньої психологічної реальності людської особистості, для якої музична мова є засадничою, але тільки однією з допустимих. Звідси зрозумілою $є$ смисло-значеннєва та технологічна єдність явищ мови - тексту - твору, або навпаки: твору тексту - мови (ця парадигматична послідовність є кільцевою, тобто циклічною, сильною саме своєю зворотною енергією).

Спираючись на певні положення праць М. Арановського, що послідовно вивчав та обговорював це парадигматичне явище смислової музичної трансляції, підкреслимо, що в процесі онтогенезу музична мова залишає враження природного походження, але водночас очевидним $є$ історичне походження виразових музичних систем. При цьому «операнди, що надаються музичному мисленню музичною мовою, існують у двох формах: у реальній звуковій, як структурні елементи вже існуючої музики, та в абстрактній, відверненій, як одиниці граматик, елементи синтактичних структур» ${ }^{19}$, тобто поєднують природні та штучні риси. Наростання штучності є очевидним, на думку Арановського, для новітніх індивідуалізованих мов-технік, для яких «категорії композиційної техніки та музичної мови практично співпадають, що вказує на тісний зв'язок творчої інтенції із самою суттю феномена мова-техніка» ${ }^{20}$.

Отже, семіологічні контексти музичної мови, діяння, сприйняття як значеннєві можуть змінюватися дуже рішуче, порушуючи навіть найбільш сталу «семантику відношень» у музиці ${ }^{21}$. Але при цьому відкритим залишається ключове питання: звідки походить, які якісні

\footnotetext{
${ }_{19}$ Арановский М. Музыка. Мышление. Жизнь: статьи, интервью, воспоминания. Москва : ГИИ, 2012. C. 108-109.

${ }^{20}$ Там само. С. 84-85.

${ }^{21}$ Там само. С. 112.
} 
ознаки ц̆ відмінності має та інформаџія та семантика, для якої призначена музична мова $?^{22}$

Спробуємо окреслити певні ракурси відповіді на таке семіологічне запитання, що дадуть змогу пропонувати специфічні аналітичні підходи.

Музичне мислення як процес передбачає зовнішнє мовне вираження $\mathrm{i}$ внутрішню форму (смислову мотивацію і впорядкованість музичної мови). Зовнішня мова і внутрішня форма в музиці істотно відрізняються від таких у словесній мові та в літературній формі: те, що для словесного (вербального) мислення $\epsilon$ внутрішньою формою, тобто смисловим надлишком, для музичного висловлювання, мовного ресурсу музики виступає вихідним змістом, тобто музика безпосередньо оперує тими смисловими коннекціями (іманентними смисло-значеннєвими зв'язками свідомості), до яких слово добирається шляхом тривалої реінтерпретації.

Музична мова, отже, здійснюється як рух від внутрішньої форми мислення, від його смисло-образно-чутної (відчутної) основи до визначеної логічної структури, і тільки потім організовує зворотний вплив, програмує за допомогою мовного прийому (винайденої знакової формули) певний іманентно-смисловий ефект. Вербалізація, участь слова дає змогу визначати зв'язки між внутрішньою та умовнозовнішньою формою в музиці, тому участь слова в музиці $є$ корисною і практично постійною, але набуває спеціальних умов та обмежень. За допомогою слова визначаються, зокрема, вектори - плани мислення та усвідомлення, способи логізації, понятійного структурування музичносмислового змісту - формування та розвитку мовного матеріалу музики.

У працях О. Самойленко ${ }^{23}$, присвячених семіологічним особливостям формотворення в музиці, розвиваються підходи до явища «внутрішньої людини», що $\epsilon$ спорідненим 3 категорією внутрішньої мови у філологічному контексті та кореспондує до знаково-значеннєвого упорядкування процесу смислового породження в музиці, зокрема, це вказівки на мотиваційно-вольовий, дієво-фізичний, емоційно-чуттєвий і когнітивний, інтелектуально-мовні рівні його втілення в музиці, 3 відповідними логічними конфігураціями.

Так, відповідно до структури «внутрішньої людини» складниками процесу семіозису в музиці є три основні етапи (три плани): комунікативно-композиційний етап / план музично-розумового (творчого) процесу; жанровий структурно-функціональний, «надихаючий»; стильовий «усвідомлюючий», рефлексивний та мотивуючий. Між першим

${ }^{22}$ Там само. С. 133.

${ }^{23}$ Самойленко О. Психологія мистецтва. Сучасні музикознавчі проєкції : монографія. Одеса : Видавничий дім «Гельветика», 2020. 236 с.

Samoilenko A.I. Form and essence as cognitive priorities of musicological scientific discourse. Musicological discourse and problems of contemporary semiology : collective monograph. Lviv-Toruń : Liha-Pres, 2020. P. 1-24. 
та другим етапами з’єднувальним початком (коннекцією) є упредметнення, «ущільнення», тобто прояв своєрідної музичної соматики, «звукової тілесності», речовності музики.

Між другим і третім як логічний зв’язок відбувається пожвавлення смислового руху, семантизація, організовується власна музична психологіка (логізація чуттєвої свідомості, виявлення «душевного ладу» музики).

У зворотному напрямі, від третього етапу до другого, проявляється автономія й активізація музичних понять, синергія музичних думок; від другого до першого - виявляються умови артефактності музики, затверджується феномен музичного твору.

Історичні типи (різновиди) музичної творчості визначають (зумовлюють) форми музичного мислення; вони передбачають особливі рефлексивні засоби музики (саморефлексію музики). Тому важливим $є$ такий історичний підхід до музично-значеннєвої системи, який переходить у семіологічний, тобто занурюється у процес мовотворення та за його допомогою у смислове буття свідомості.

Як неодноразово писав про це М. Мамардашвілі ${ }^{24}$, людина весь час змушена враховувати попереднє своє існування і можливу в майбутньому історію людства, оскільки вона визначає архетипи його свідомості. Завдяки їй вона народжується не в порожнечі, а в «заселеному» світі; діє не сама по собі, а внаслідок особливої приналежності, залученості до людства, в інтересах цього людства; залежить від тих завдань, які ставить перед нею історія людства, але і вносить в їх рішення і подальшу постановку свою лепту. На погляд Мамардашвілі і деяких інших авторів, саме подібний екзистенціальний зв'язок 3 людством, що пояснює наявність вищих соціальних, у тому числі творчих духовних, потреб є для людини запорукою меморіальної пам'яті - своєрідного безсмертя.

Іманентні значеннєві коннекції, як внутрішня форма думки, структуровані відповідно до рівнів/планів «внутрішньої людини» (тобто упорядкованого змісту цілісної людської свідомості, котра охоплює людський досвід повністю, розміщує та комплектує його за напрямами, що йдуть від головних прецедентних смислів), і $є$ тією інформацією, що лягає в основу власних понятійно-знакових структур музики.

Мова музики таким чином сприяє проясненню, саморефлексії свідомості, пред'являє їй можливості власного змісту, і ц̧е ї̈ провідна системна семантична функизія.

Слуховий образ (передчуття смислу) та породжувані ним значеннєві коннекції продукують мовний вибір, визначають специфіку знакових форм, зумовлюють те, яким чином реалізуються смислові завдання свідомості.

\footnotetext{
24 Мамардашвили М. Эстетика мышления. Беседы. Москва, 2000. Центр гуманитарных технологий. URL: https://gtmarket.ru/laboratory/basis/5061.
} 
Що стосується семантичного плану музичної композиції, то він виявляє подвійність і перехідне положення, з одного боку, справді, продовжуючи низку логіко-предметних накопичень («що»), оскільки входить у систему упредметнення часу в музичній матерії, а з іншого відсилаючи до вихідних якостей звукосмислу, підтверджуючи негентропійність музики як системи ціннісних відносин 3 часом, як упорядкованого часу (до «як»).

Стосовно так званих прецедентних або попередніх меморіальномнемонічних смислів, то «семантика прецедентного» в музиці має на увазі опору на історичний досвід та наявність власних «історичних апріорі», що парадоксальним чином презентують саме загальновизнані досвідні результати, досягнення. Досвід музичної творчості (мислення) закріплюється в музичних артефактах, у тому числі в творах (завершених текстових формаціях), які забезпечують пролонговані зв'язки між прецедентними смислами (загальними обов'язковими смисловими установками) i структурно-семантичними формулами музики. Останні сприймаються як іманентні музичні епістеми - опорні пункти музичної свідомості.

Тому художнім матеріалом епістемологічного аналізу музики $є$ той, який дозволяє реконструювати прямі і зворотні зв'язки музичних значень на шляху формування цілісної семантичної системи музики, тобто свідчить про відкритий характер смислової системи музичної творчості. Він також дозволяє визначати музикальність як ключовий концепт іманентного змісту музики, ії власний «квантор всезагальності».

3 репрезентуючих епістемологічний підхід у музикознавстві понять виділяються ті, що пов'язані з параметрами внутрішнього, насамперед внутрішньої форми мови як особливої природно-штучної форми творчого процесу, мислення, свідомості, як засобу системної побудови внутрішнього світу особистості та художнього світу музики в їх безперечній єдності і цілісності. Їх обговорення веде до відокремлення понять про автономні функціональні системи музичної мови та музичномовної свідомості, також до структурації-стратифікації (первинне, вторинне, третинне середовища та далі; композиторські, виконавські та слухацько-реципієнтні аспекти і т. ін.) текстуально-стилістичного конгломерату музичної мови як власної іманентної мови людської свідомості.

\section{ВИСНОВКИ}

Семіологічна вмотивованість музикознавчого пізнання дозволяє визначати, що питання про сутність мистецтва солідарне 3 питанням про головний закон людської самосвідомості: про людяність як «точку зборки» людини, істоти мислячої та відчуваючої, яка розуміє і говорить, 
тобто виражає свої думки і почуття в системі висловлювань за допомогою мови. Зрештою, це питання набуває широкого ноетичного резонансу, звертаючись до ідеї всезагального духу, що вселяється в людську індивідуальність; воно веде також до психологічної заглибленості у зв'язку з вивченням модальностей людської свідомості як ідеально-віртуальних субстанцій, що забезпечують континуальність та динаміку музичного мислення.

Як аналітичні пропозиції семіологічної концепції відзначимо такі чотири етапи формування музичного смисло-значення: матеріальнофізичний, звуко-організаційний, фонемно-сонорний; сугестивноемпатійний, комунікативний (єднальний), інтонаційно-мовний; конструктивно-відокремлюючий, композиційно-інтерпретуючий; розуміючий, узагальнюючий, абстрагований та концептуалізований.

3 них перший характеризує матеріальну природу музичної мови, iii знакову матерію і перцептивну призначеність; перший i другий в їх єдності стають платформою появи жанрових властивостей (структур) музики; другий і третій представляють умови формування музичного твору i стилістики, тобто єдиного композиційно-текстового поля музики; четвертий дозволяє відокремлюватися стильовому змісту музики, є відповідальним за всі процеси семантичної репрезентації. Саме цей заключний i узагальнюючий рівень становлення i діяння музики стає опорним для діалогу з музичною думкою, з мовою музики. Але діалогічними якостями володіють й власні мовні механізми музичного мистецтва, тому діалогічні риси музичної семіології зумовлені їі специфічним предметом, яким є мовна єдність смислового змісту, знаково-значеннєвих умов та критеріїв діяння й сприйняття музики у контексті людської комунікації та у процесі становлення й самовиявлення музичної свідомості (див. с. 4 цієї роботи).

Але головне, і це вже мета музично-семіологічного дослідження розгледіти та визначити у цьому процесі та його результатах систему формування музичних значень, тобто нероздільних та незлиянних музичних звучань, конгломерат яких репрезентує власну художньосмислову реальність музики.

\section{АНОТАЦІЯ}

Це дослідження зумовлене потребою музикознавства та гуманітарного знання загалом у знаходженні інтегративних теорій, здатних виявляти мовний інструментарій людської свідомості. Головною метою його є визначення предмета, власної структури, категоріальної основи музичної семіології як освітньо-наукової дисципліни, що покликана розкривати призначення музичної мови у смислотворчому бутті людини як в іiі справжній природно-штучній реальності з властивістю самозростання. 
Використовуються системно-дискурсивний метод в єдності 3 епістемологічним підходом, розвивається розуміючий діалогічний напрям музикознавчої теорії (метатеорії), узагальнюючої семіологічні поняття в їх проєкції до питань музично-мовної свідомості. Встановлюються специфічні риси взаємодії знаку, значення, смислу в музиці, соціокультурні чинники музичної семіології та іiі «антропологічне середовище», музично-семіологічні трикутники «смисл - значення знак», «текст - мова - смисло-значеннєва свідомість»; обговорюються явища внутрішньої форми мови та внутрішньої реальності музики, запроваджується поняття «музика conscientia», визначається взаємозв'язок явищ/понять ноосфери, фоносфери, семіосфери, виокремлюється та вивчається феномен музичного звуку. Доводиться необхідність створення теорії музичних значень, оскільки вона відкриває внутрішне буття музичного тексту, його генеральну властивість - транзитивність, спроможність передавати структурно-семантичні функції від однієі множини стилістичних фігур через іншу далі. Виявляється смислозначеннєва та технологічна єдність явищ мови - тексту - твору в музиці. Як головне семіологічне питання розглядається питання про якісні ознаки й відмінності тієї інформації та семантики (способу смислових означень), для яких призначена музична мова.

\section{ЛІТЕРАТУРА}

1. Арановский М. Музыка. Мышление. Жизнь: статьи, интервью, воспоминания. Москва : ГИИ, 2012. 439 с.

2. Барт Р. Основы семиологии. / Перевод с французского Г.К. Косикова. Структурализм: «за» $u$ «против» : сборник статей. / Пер. с английского, французского, немецкого, чешского, польского и болгарского языков: под редакцией Е.Я. Басина и М.Я. Полякова. Москва : «Прогресс», 1975. С. 114-163.

3. Бахтин М. Автор и герой в эстетической деятельности. Эстетика словесного творчества. 2-ое изд. / Сост. С. Бочаров. Прим. С. Бочарова и С. Аверинцева. Москва : Искусство, 1986. С. 9-191.

4. Бахтин М. К философии поступка. Работы 1920-х годов. Киев : Наукова думка, 1994. С. 9-68.

5. Бахтин М. Слово в романе. Вопросы литературы и эстетики. Исследования разных лет. Москва : Художественная литература, 1975. C. $72-233$.

6. Бахтин М. Эпос и роман. Вопросы литературы и эстетики. Исследования разных лет. Москва : Художественная литература, 1975. C. 447-483. 
7. Бахтин М. Проблема текста в лингвистике, филологии и других гуманитарных науках. Литературно-критические статьи. Москва : Художественная литература, 1986. С. 473-500.

8. Буш Г. Диалогика и творчество. Рига : Авотс, 1985. 318 с.

9. Выготский Л. Проблема сознания. Собр. соч. в 6-ти томах. Т. 1./ Под ред. А. Лурия, М. Ярошевского. Москва : Педагогика, 1982. С. $156-167$.

10. Выготский Л. О психологических системах. Собр. соч. в 6-ти томах. Т.1. / Под ред. А. Лурия, М. Ярошевского. Москва : Педагогика, 1982. C. 109-131.

11. Выготский Л. Мышление и речь. Собр. сочинений: в 6 т. Т. 2. Москва : Педагогика, 1982. С. 361.

12. Герасимова-Персидская Н. Звук и знак в музыкальном искусстве. Киїське музикознавство: Музикознавство у діалозі. Київ-Дюссельдорф, 2011. Вип. 37. С. 12-23.

13. Мамардашвили М. Эстетика мышления. Беседы. Москва, 2000. Центр технологий. URL: https://gtmarket.ru/laboratory/basis/5061;

14. Мамардашвили М. Мой опыт нетипичен. Санкт-Петербург : Азбука, 2000. 400 с.

15. Орлов Г. Древо музыки. Н.A. Frager \& Со. «Советский композитор». Вашингтон-Санкт-Петербург. 1992. 440 с.

16. Самойленко А. Культурологическая концепция диалога М. Бахтина и методологические проблемы музыкознания. Культурологічна трансформація мистецької освіти та актуальні питання творчої діяльності музиканта в сучасній Украӥні. Збірник наукових праць. Київ, 1998. С. 21-37.

17. Самойленко А. Музыковедение и методология гуманитарного знания. Проблема диалога. Одесса : Астропринт, 2002. 244 с.

18. Самойленко О. Психологія мистецтва. Сучасні музикознавчі проєкції : монографія. Одеса : Видавничий дім «Гельветика», 2020. $236 \mathrm{c}$.

19. Стогний И. Коннотативные свойства музыкального текста : монография. Москва : РАМ им. Гнесиных. 2013. 224 с.

20. Стогний И. Процессы смыслообразования в музыке (семиологический аспект) : дисс. доктора искусствоведения; спец. : 17.00.02 «Музыкальное искусство». Москва : РАМ им. Гнесиных, 2013. $416 \mathrm{c}$.

21. Тараканова Е. Концепция фоносферы на рубеже тысячелетий. Звуковая среда современности : сб. ст. памяти М. Тараканова (19281996). / Отв. ред.-сост. Е. Тараканова. Москва : ГИИ, 2012. С. 27-41. 
22. Торопова А. Интонирующая природа психики: музыкальнопсихологическая антропология : монография. 2-е изд. Москва : МПГУ, $2018.338 \mathrm{c}$.

23. Флоренский П. Из богословского наследия. Богословские труды. Москва, 1977. T. XVII. С. 85-248.

24. Хоффман И. Активная память. Экспериментальные исследования и теория человеческой памяти. / Пер. с нем. К.М. Шоломия. Москва : Прогресс, 1986. 309 с.

25. Эко У. Отсутствующая структура. Введение в семиологию. / Пер. с итал. В. Резник и А. Погоняйло. Санкт-Петербург : «Симпозиум», 2004. $544 \mathrm{c}$.

26. Wertsch J.V. The significance of dialogue in Vygotsky's account of social, egocentric, and inner speech. Contemporary Educational Psychology, No. 5, 1980. Pp. 150-162.

27. Samoilenko A.I. Form and essence as cognitive priorities of musicological scientific discourse. Musicological discourse and problems of contemporary semiology : collective monograph. Lviv-Toruń : Liha-Pres, 2020. Pp. 1-24.

\section{Information about authors:}

Samoilenko O. I.,

Doctor of art History, Professor, Vice-Rector for Research

Odessa National A. V. Nezhdanova Academy of Music 63, Novoselsky str., Odessa, 65023, Ukraine Osadcha S. V.,

Doctor of art History, Professor, Head of the Department of Music History and Musical Ethnography Odessa National A. V. Nezhdanova Academy of Music 63, Novoselsky str., Odessa, 65023, Ukraine 